\title{
Influence of organo-mineral supplementation on the production of secondary metabolites in in vitro-germinated Bromelia balansae Mez.
}

Influência da suplementação organo-mineral na produção de metabólitos secundários em Bromelia balansae Mez. germinada in vitro

Influencia de la suplementación organomineral en la producción de metabolitos secundarios en Bromelia balansae Mez. germinadas in vitro

Received: 07/09/2021 | Reviewed: 07/18/2021 | Accept: 09/03/2021 | Published: 09/05/2021

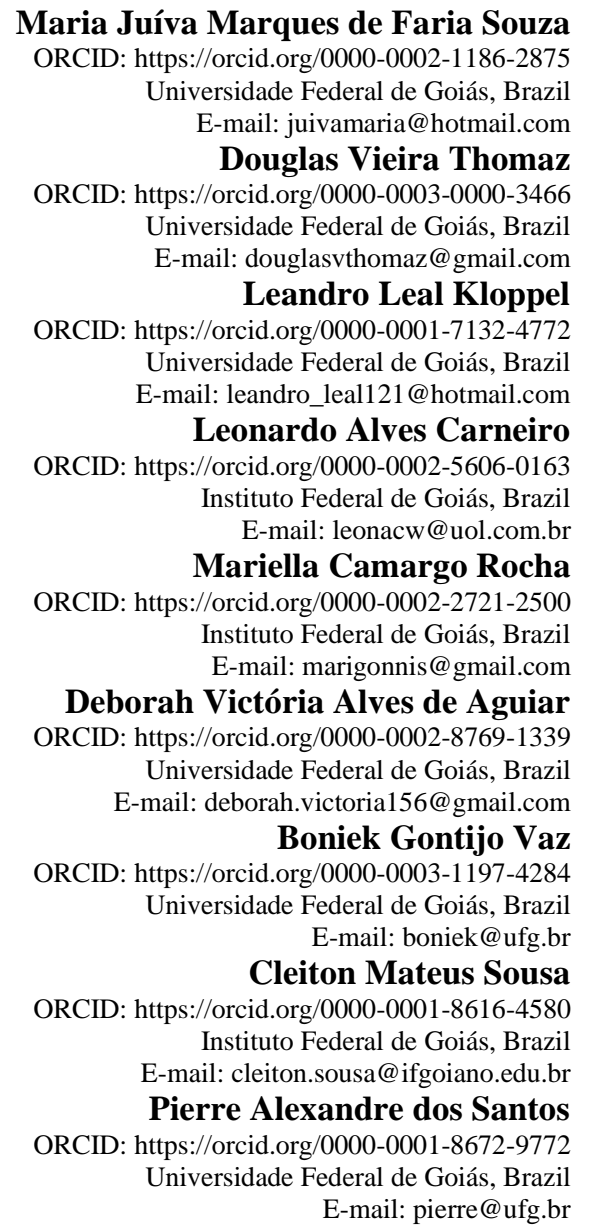

\begin{abstract}
This work details the investigation of the influence of organo-mineral supplementation on the production of secondary metabolites in in vitro-germinated Bromelia balansae Mez. The seeds were germinated in vitro and transplanted to standard soils to undergo organo-mineral supplementation. The fully-grown plants were subjected to qualitative phytopharmacological prospection; quantitative analysis of total phenols and flavonoids; as well as chemical profiling by mass spectrometry. The in vitro germination of $B$. balansae was successful, with a germination rate of $94.95 \%$, thereby equaling to "super seeds" reported in literature. Moreover, the organo-mineral supplementation enhances the production of secondary metabolites in both leaves and roots, what therefore leads to higher yield of total phenols and flavonoids. Furthermore, mass spectrometry analysis confirmed the results from phytopharmacological prospection, and allowed the detection of fragments of secondary metabolites from shikimate/polyketide/mevalonate pathways. Keywords: Phytochemistry; Germination in vitro; Nutrient; Mass spectrometry; Natural product.
\end{abstract}




\section{Resumo}

Este trabalho detalhou a investigação da influência da suplementação organo-mineral na produção de metabólitos secundários em Bromelia balansae Mez. germinada in vitro. As sementes foram germinadas in vitro e transplantadas para solos padrão para suplementação organo-mineral. As plantas totalmente crescidas foram submetidas a prospecção fitofarmacológica qualitativa; análise quantitativa de fenóis e flavonóides totais; bem como perfis químicos por espectrometria de massa. A germinação in vitro de B. balansae foi bem-sucedida, com taxa de germinação de 94,95\%, igualando-se às "super sementes" relatadas na literatura. Além disso, a suplementação organo-mineral aumentou a produção de metabólitos secundários tanto nas folhas quanto nas raízes, o que, portanto, levou a um maior rendimento de fenóis e flavonóides totais. Além disso, a análise por espectrometria de massa confirmou os resultados da prospecção fitofarmacológica e permitiu a detecção de fragmentos de metabólitos secundários das vias do chiquimato/ policetídeo / mevalonato.

Palavras-chave: Fitoquímica; Germinação in vitro; Nutriente; Espectrometria de massa; Produto natural.

\section{Resumen}

Este trabajo detalla la investigación de la influencia de la suplementación organomineral en la producción de metabolitos secundarios en Bromelia balansae Mez. germinada in vitro. Las semillas se germinaron in vitro y se trasplantaron a suelos estándar para someterse a una suplementación organomineral. Las placas completamente desarrolladas se sometieron a prospección fitofarmacológica cualitativa; análisis cuantitativo de fenoles y flavonoides totales; así como el perfilado químico por espectrometría de masas. La germinación in vitro de B. balansae fue exitosa, con una tasa de germinación del 94,95\%, lo que equivale a las "super semillas" reportadas en la literatura. Además, la suplementación organomineral mejora la producción de metabolitos secundarios tanto en hojas como en raíces, lo que conduce a un mayor rendimiento de fenoles y flavonoides totales. Además, el análisis de espectrometría de masas confirmó los resultados de la prospección fitofarmacológica y permitió la detección de fragmentos de metabolitos secundarios de las rutas de shikimato / policétido / mevalonato.

Palabras clave: Fitoquímica; Germinación in vitro; Nutritivo; Espectrometría de masas; Producto natural.

\section{Introduction}

The understanding of the growth and development of plants is essential to shed light on the underlying mechanisms regarding secondary metabolite production and for phytopharmacological prospection (Jamwal et al., 2018). In this regard, many authors highlighted the effects of exogenous factors on vegetal metabolism and development, such as nitrogen and phosphate supplementation (i.e. organic supplementation) as well as the use of mineral macro and micronutrients (e.g. potassium, calcium and others) (Baliza et al., 2012; Bem Junior et al., 2019; da Silva et al., 2017). Albeit the inclusion of these nourishments was extensively studied regarding overall vegetal growth and development, their influence on the expression of secondary metabolites of interest in medicine is still not fully understood(Yang et al., 2018).

Secondary metabolites are natural products derived from particular biochemical pathways which are not outright needed to plant life, though play a definitive role in their survival(Sanchez et al., 2019). Amongst the most known secondary metabolites are phenolic compounds (e.g. flavonoids, tannins, anthocyanins and anthraquinones); amino moiety-bearing products (e.g. alkaloids and methylxanthines); as well as coumarins, saponins and others. Nonetheless, the sheer chemical diversity of secondary metabolites leads to their pharmacognostic classification according to their source-metabolic pathway or shared structural features (Isah, 2019).

Considering the variable chemical structure of plant secondary metabolites, it is widely understood that these compounds also showcase a plethora of different uses in medicine. For instance, the uptake of phenolic compounds such as flavonoids, tannins and anthocyanins has been reported to lead up to strong antioxidant and anti-inflammatory activity in animal models; showcasing therapeutic effects even in hard-to-reach tissues such as in the central nervous system (Alves et al., 2020; Oliveira et al., 2018; Thomaz et al., 2018a), while alkaloids have a lengthy historic use in occidental medicine to suppress pain and induce anesthesia (Neto et al., 2019; Zhu et al., 2020). In this sense, the myriad of therapeutic applications of plant secondary metabolites highlights the relevance of understanding the factors which might promote or hinder their expression during plant development.

Amongst the herbs which are known to have a variety of therapeutic uses is Bromelia balansae Mez. This vegetal is a 
terrestrial Bromeliaceae native to South America which is employed as a cough suppressant in Brazilian folk medicine and also as an emergent and affordable source of cellulose for biotechnological and pharmaceutical applications (Corrêa et al., 2019; da Silva Balin et al., 2018; Romero et al., 2006). Despite its relevance and uses, B. balansae populations are decreasing owing to the advance of the monoculture of commodity crops in some regions of the Brazilian Cerrado, thereby leading to the need of repopulation interventions.

Considering the relevance of repopulating $B$. balansae in its habitat, and also the benefits of using self-contained experimental models such as in vitro growth to better shed light on the influence of exogenous factors such as nutritional supplementation in the expression of plant secondary metabolites, this work therefore details the investigation of the influence of organo-mineral supplementation on the production of secondary metabolites in vitro-germinated B. balansae.

\section{Methodology}

\section{In vitro germination}

The seeds of B. balansae were acquired in November $20^{\text {th }}, 2015$, in the Botanical Garden of Brasília, Federal District, Brazil. Immediately after collection, the seeds were immersed in hydroethanolic solution (70\% v:v, ethanol:water) for 1 minute under laminar flow. Thereafter, the seeds were rinsed with deionized water and then immersed in sodium hypochlorite solution (5\% v:v) with $1.0 \%$ polysorbate 80 . After immersion in hypochlorite solution, the seeds were rinsed for 5 minutes with deionized water. These procedures were performed to avoid any microbial contamination.

Then the seeds were added to $10 \mathrm{ml}$ flasks containing half-diluted Murashige-Skoog medium, which was prepared according to a standard protocol. The growth flasks were stored at $25 \pm 2{ }^{\circ} \mathrm{C}$ under 16 hours of photoperiod. Light intensity was of $50 \mu \mathrm{mol}$ of photons $\mathrm{m}^{-2} \mathrm{~s}^{-1}$, which was achieved with white light-emitting diodes. The seeds were allowed to germinate until the vegetal material lenghted $2.5 \mathrm{~cm}$, after which they were transplanted to a standardized soil for growth.

\section{Bromelia balansae transplant and growth in standard soil}

The in vitro germinated vegetal material was thoroughly rinsed with water and transplanted to polystyrene supports containing a standardized soil. The supports were displaced horizontally outdoors at the Federal Institute of Goiás in Ceres,

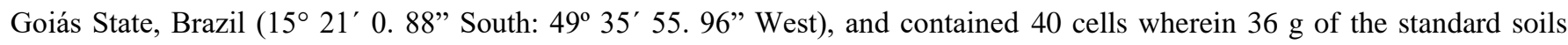
Carolina Soil ${ }^{\circledR}$ and Tropstate Florestal ${ }^{\circledR}$ were added at the proportion of 1:3, respectively. The crops underwent irrigation by aspersion for 3 minutes, 4 times-a-day. Moreover, every 15 days the cells were added of $10 \mathrm{ml}$ of half-diluted Hoagland \& Arnon ${ }^{\circledR}$ nutrient solution.

\section{Organo-mineral supplementation}

After 3 months of growth in the standard soils, the plants were then transplanted to $626 \mathrm{~g}$ (1:3, Carolina Soil ${ }^{\circledR}$ :Tropstate Florestal ${ }^{\circledR}$ ) plant pots, being 2 plants in each. Therefore, 64 plants were transplanted to 32 plant pots containing standard soil. Thereafter, half of the plant pots (i.e. 16) was added of $30 \mathrm{~g}$ of organo-mineral supplementation, being their average $\mathrm{pH}$ of 6.70 , while those left without supplementation averaged 6.31. The plant pots underwent irrigation by aspersion under the same protocol as previously described in 2.2, and the organo-mineral supplement was composed of: $120 \mathrm{~g}$ bentonite; $670 \mathrm{~g}$ of chicken bedding (wood shavings and rice straw); $330 \mathrm{~g}$ monoammonium phosphate and $2 \%$ sodium silicate solution. After 9 months, the fully grown plants were transplanted into $10 \mathrm{~kg}$ plant pots, of organo-mineral supplementation and without supplementation, and underwent the same irrigation protocol as previously described. In the $10^{\text {th }}$ month, the plants were collected for phytochemical prospection and further experiments. 


\section{Coding and sample preparation}

The plants were separated into two parts, namely: leaves and roots. The leaves from the plants which underwent organo-mineral supplementation were coded $\mathrm{L}+$, while the leaves from them plants that did not undergo supplementation were coded L-. The roots were coded in a similar fashion, being those from supplemented plants coded $\mathrm{R}+$, while the nonsupplemented were coded R-. For each experiment, 6 plants were randomly selected from each group (i.e. supplemented and non-supplemented) and a small amount of vegetal material was retrieved in order to not compromise the plant after this study was finished. The samples of leaves and roots were dried under ventilation until constant weight under $40{ }^{\circ} \mathrm{C}$ and thereafter milled to a powder, which was stored in sterile plastic bags under refrigeration.

\section{Qualitative phytochemical prospection}

Phytochemical prospection was conducted according to standard protocols which describe the qualitative colorimetric analysis of raw vegetal mater. The samples were investigated for:

- anthraquinones (i.e. through Borntraeger reaction)(Matias et al., 2019);

- phenols through three different methods (i.e. reaction with alkaline hydroxides; reaction with aluminum hydroxide; and use of iron chloride as chromogen)(Alves et al., 2020; Delgado et al., 2019);

- flavonoids through three different methods (i.e. reaction with cyanidin; oxalo-boric reaction; and Shinoda reaction)(Matias et al., 2019);

- $\quad$ saponins (through the formation of foam)(Majinda, 2012);

- coumarins (through reaction with alkaline hydroxides)(Hroboňová et al., 2020);

- tannins through four different methods (i.e. formation of complexes with gelatin; reaction with copper acetate; reaction with iron chloride; and reaction with alkaline hydroxides)(Matias et al., 2019);

- alkaloids through six different methods (i.e. use of Mayer, Dragendorff, Bouchardat, Bertrand, and Hager reagents, and reaction with tannic acid)(Matias et al., 2019);

- methylxanthines (through murexide test)(Mohana et al., 2012).

\section{Quantification of total phenols and total flavonoids}

The quantification of total phenols was conducted according to a standard protocol described by Hagerman and Butler, wherein iron chloride is used as a chromogen and spectrophotometric reading is conducted at $510 \mathrm{~nm}$, while the total phenols are calculated as tannic acid equivalents (Mole et al., 1987). The quantification of flavonoids followed the method described elsewhere using rutin equivalents and spectrophotometric readings conducted at $361 \mathrm{~nm}$ (José et al., 2019).

\section{Chemical profiling through mass spectrometry}

In order to promote the chemical profiling of the leaves and roots to better understand the influence of organo-mineral supplementation on the expression of secondary metabolites, mass spectrometry was conducted. Therefore, $20 \mathrm{mg}$ of each sample was added of $1 \mathrm{ml}$ hydroethanolic solution ( $80 \% \mathrm{v}: \mathrm{v}$, ethanol:water), and then centrifuged at $4000 \mathrm{rpm}$ (1789 relative centrifugal force $-\mathrm{g}$ force) for $20 \mathrm{~min}$. Thereafter, the supernatant was added of $1 \mathrm{ml}$ hexane and subjected to 10 minutes of ultrasound treatment. Then, the hexane fraction was discarded and the hydroethanolic fraction was subjected to mass spectrometry.

The mass spectrometry analysis was conducted in a micro-Time of Flight III (Brucker Daltonics, Bremen, Germany) equipped with an Electrospray Ionization (ESI) source (Brucker Daltonics, Bremen, Germany). The samplings were performed 
by direct infusion $\left(3 \mu \mathrm{min}^{-1}\right)$. All mass spectrometry assays were performed considering $[\mathrm{M}+\mathrm{H}]+$ positive mode (ESI+). The nitrogen nebulizer and capillary temperatures were set to $200{ }^{\circ} \mathrm{C}$ under a pressure of 0.4 bar. The flow rate was of $41 \mathrm{~min}^{-1}$ and the capillary voltage was of $-4 \mathrm{kV}$. The end plate offset was of $-500 \mathrm{~V}$ and the skimmer was of $35 \mathrm{~V}$, with a voltage collision of -1.5 V. Each spectrum was collected upon 2 micro scans, and all information was treated on Data Analysis software (Brucker Daltonics, Bremen, Germany) (Silveira et al. 2019).

The $\mathrm{m} \mathrm{z}^{-1}$ data was investigated through Competitive Fragmentation Modeling for Metabolite Identification (CFM-ID) according to previous protocols through the input of the Simplified Molecular-Input Line-Entry System (SMILES) of each proposed progenitor molecule, which was itself retrieved from PubChem database (Allen et al., 2015; Hufsky et al., 2017). Each progenitor molecule was selected and investigated according to previous reports concerning their detection in Bromeliaceae samples through mass spectrometry. Moreover, each fragment was evaluated according to their $\mathrm{m} \mathrm{z}^{-1}$ and relative abundance considering $[\mathrm{M}+\mathrm{H}]+(\mathrm{ESI}+)$.

\section{Statistical analysis}

Statistical analysis was performed by analysis of variance between the data regarding the leaves and the roots of the plants which were and were not subjected to organo-mineral supplementation. Therefore, Tukey's test was used considering a confidence interval of 95\% (Rouder et al., 2016).

\section{Results and Discussion}

\section{In vitro germination}

The germination rate of $B$. balansae was of $94.95 \%$ and the plants grew uniformly. Moreover, there was no visible microbial contamination in the medium (i.e. biomass and mycelia formation, as well as changes in color and odor).

\section{Qualitative phytochemical prospection and quantification of total phenols and total flavonoids}

In order to preliminarily shed light on B. balansae chemical constitution and its possible changes under and without organo-mineral supplementation, a qualitative phytochemical prospection was conducted. Results are presented in Table 1, and are coded as positive (+); thereby indicating the occurrence of the reaction, or negative (-); thereby indicating the absence of reaction. Moreover, the results of the quantitative analysis are showcased in Table 2. 
Table 1. Qualitative phytochemical prospection of the leaves and roots of organo-mineral-supplemented and nonsupplemented Bromelia balansae Mez. plants. Positive results are colored in light grey while negative results are colorless.

\begin{tabular}{|c|c|c|c|c|c|}
\hline Secondary metabolite & Test & $\mathbf{L}+$ & L- & $\mathbf{R +}$ & R- \\
\hline Anthraquinones & Borntraeger: reaction & - & - & - & - \\
\hline \multirow{3}{*}{ Flavonoids } & Cyanidin reaction (flavones) & + & + & - & - \\
\hline & Oxalo-boric reaction & - & - & + & + \\
\hline & Sulfuric acid reaction & + & + & + & + \\
\hline \multirow{3}{*}{ Phenolic compounds } & Alkaline hydroxide reaction & + & + & + & + \\
\hline & Aluminum chloride reaction & + & + & + & + \\
\hline & Iron Chloride reaction & + & + & + & + \\
\hline Saponins & Foam formation & - & - & - & - \\
\hline Coumarins & Alkaline hydroxides reaction & + & + & + & + \\
\hline \multirow{4}{*}{ Tannins } & Complexes with gelatin & - & - & - & - \\
\hline & Copper acetate reaction & - & - & + & + \\
\hline & Iron chloride reaction & - & - & + & + \\
\hline & Alkaline hydroxides reaction & + & + & + & + \\
\hline \multirow{6}{*}{ Alkaloids } & Mayer reaction & - & - & - & - \\
\hline & Dragendorff reaction & + & + & + & + \\
\hline & Bouchardat reaction & + & + & + & + \\
\hline & Bertrand reaction & - & - & - & - \\
\hline & Hager reaction & + & + & + & + \\
\hline & Tannic acid reaction & - & - & - & - \\
\hline Methylxantines & Murexide reaction & - & - & - & - \\
\hline
\end{tabular}

Source: Authors.

Table 2. Quantification of the total phenols and flavonoids in the leaves and roots of organo-mineral-supplemented and nonsupplemented Bromelia balansae Mez. plants. All data showcased statistically significant difference, and is showcased in \% of tannic acid equivalents for total phenols and $\%$ of rutin equivalents for flavonoids.

\begin{tabular}{ccc}
\hline Total phenolic content (\%) & Supplemented (+) & Non-supplemented (-) \\
\hline $\mathbf{L}$ & $0.30 \% \pm 0.0004 \mathrm{Ba}$ & $0.25 \% \pm 0.0011 \mathrm{Ab}$ \\
$\mathbf{R}$ & $0.56 \% \pm 0.0004 \mathrm{Aa}$ & $0.19 \% \pm 0.0007 \mathrm{Bb}$ \\
\hline Flavonoid content (\%) & Supplemented (+) & Non-supplemented (-) \\
\hline $\mathbf{L}$ & $1.06 \% \pm 0,0022 \mathrm{Ba}$ & $0.92 \% \pm 0.0040 \mathrm{Ab}$ \\
$\mathbf{R}$ & $1.64 \% \pm 0,0022 \mathrm{Aa}$ & $0.29 \% \pm 0.0004 \mathrm{Bb}$ \\
\hline
\end{tabular}

Means followed by the same uppercase letter in the column and means with the same lowercase letter in the rows do not differ statistically from each other, by Tukey's test, at the level of 5\% probability. Source: Authors.

\section{Chemical profiling through mass spectrometry}

In order to promote the chemical profiling of the leaves and roots of $B$. balansae and understand the influence of organo-mineral supplementation, mass spectrometry was conducted. Mass spectra of the leaves is showcased in Figure 1, while the roots are presented in Figure 2. Moreover, main spectral data and correlations are depicted in Table 3. 
Figure 1. A. Mass spectra of the leaves from organo-mineral supplemented Bromelia balansae Mez. plants (L+). B. Mass spectra of the leaves from non-supplemented B. balansae plants (L-). Data acquired in micro-Time of Flight III mass spectrometer equipped with an Electrospray Ionization set to positive mode ([M+H]+/ESI+).
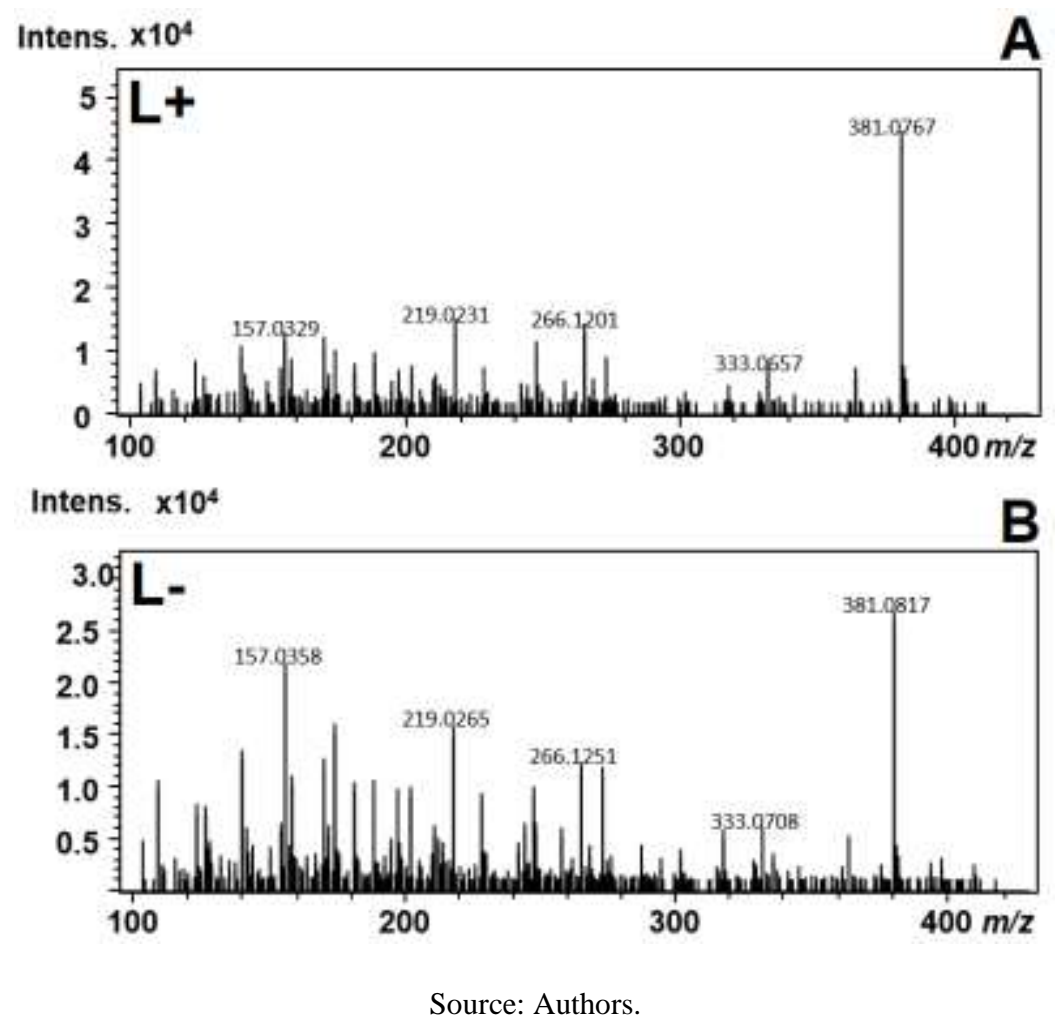

Figure 2. A. Mass spectra of the roots from organo-mineral supplemented Bromelia balansae Mez. plants (R+). B. Mass spectra of the roots from non-supplemented B. balansae plants (R-). Data acquired in micro-Time of Flight III mass spectrometer equipped with an Electrospray Ionization set to positive mode $([\mathrm{M}+\mathrm{H}]+/ \mathrm{ESI}+)$.
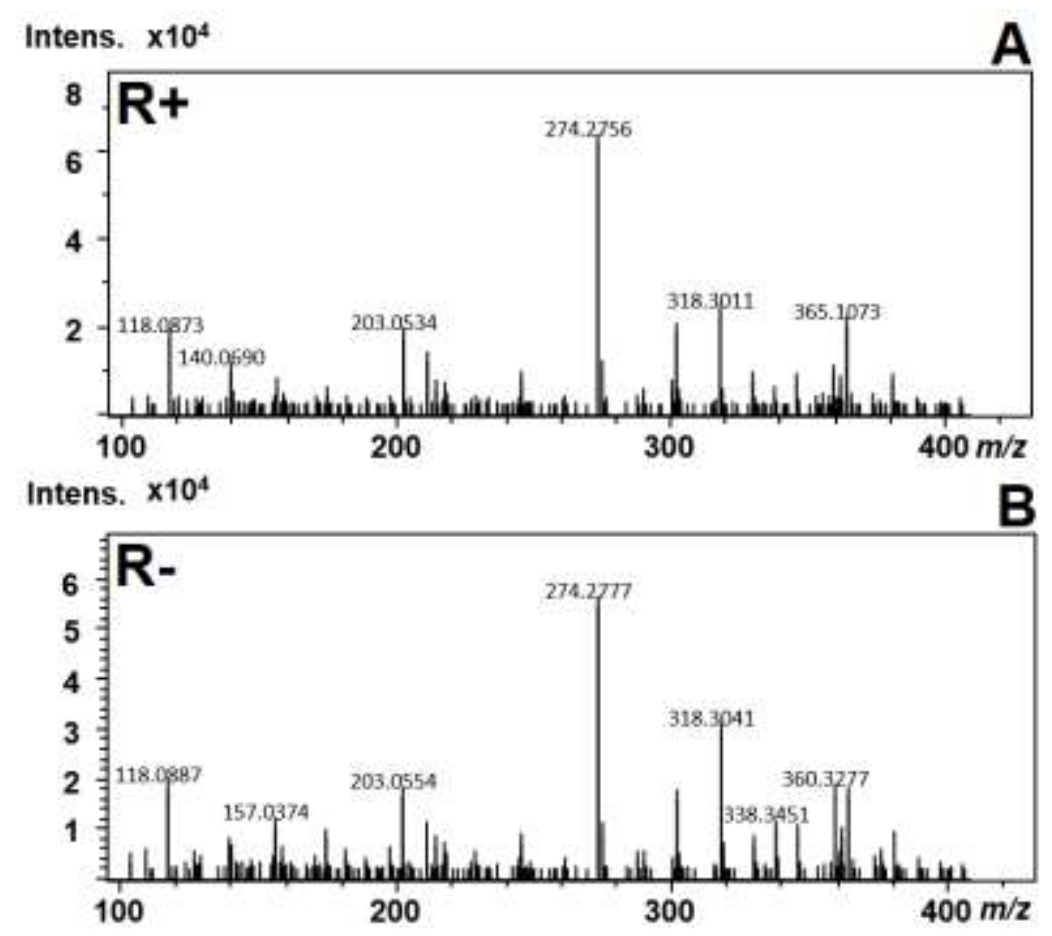

Source: Authors. 
Table 3. Chemical profiling of the main signals from the mass spectrometry analysis of the leaves and roots of organomineral-supplemented and non-supplemented Bromelia balansae Mez. plants. The fragments are characterized according to $\mathrm{m}$ $\mathrm{z}^{-1} ; \mathrm{m} \mathrm{z}^{-1}$ error $(\%)$; chemical formula; possible chemical structures and origin upon $[\mathrm{M}+\mathrm{H}]+/ \mathrm{ESI}+$ fragmentation. The origin was grouped according to the progenitor molecule/metabolic pathway, namely: alkaloid (amino acids); furanocoumarin (shikimate/polyketide/mevalonate pathways); polyphenol (shikimate/polyketide); and glycoside (aglycone bound to monosaccharides).

\begin{tabular}{|c|c|c|c|c|}
\hline $\mathrm{m} \mathrm{z}^{-1}$ & error (\%) & Chemical formula & Proposed fragments & Fragment origin \\
\hline 118.0873 & 0.0146 & $\mathrm{C}_{8} \mathrm{H}_{8} \mathrm{~N}^{+}$ & & Alkaloid \\
\hline 140.0690 & 0.0135 & $\mathrm{C}_{10} \mathrm{H}_{6} \mathrm{~N}^{+}$ & & Alkaloid \\
\hline 159.0451 & 0.0032 & $\mathrm{C}_{10} \mathrm{H}_{7} \mathrm{O}_{2}{ }^{+}$ & & Furanocoumarin \\
\hline 157.0329 & 0.006 & $\mathrm{C}_{7} \mathrm{H}_{9} \mathrm{O}_{4}{ }^{+}$ & & Polyphenol \\
\hline 173.0581 & 0.0299 & $\mathrm{C}_{11} \mathrm{H}_{13} \mathrm{~N}_{2}{ }^{+}$ & & Alkaloid \\
\hline 203.0534 & 0.0113 & $\mathrm{C}_{11} \mathrm{H}_{7} \mathrm{O}_{4}^{+}$ & & Furanocoumarin \\
\hline 219.0265 & 0.0015 & $\mathrm{C}_{11} \mathrm{H}_{7} \mathrm{O}_{5}^{+}$ & & Polyphenol \\
\hline 365.1073 & 0.0019 & $\mathrm{C}_{21} \mathrm{H}_{17} \mathrm{O}_{6}{ }^{+}$ & & $\begin{array}{l}\text { Polyphenol } \\
\text { (glycoside) }\end{array}$ \\
\hline
\end{tabular}

Source: Authors.

Mass spectra of the leaves and roots showcased that both the supplemented and non-supplemented plants exhibit signals at nearly identical $\mathrm{m} \mathrm{z}^{-1}$ considering paired comparison according to tissue ( $\mathrm{L}+$ to $\mathrm{L}-$ and $\mathrm{R}+$ to $\mathrm{R}-$ ), though their relative abundance increases in the absence of supplementation (Figure 1 and 2). The correlation of the main signals with possible fragments through CFM-ID and the databases suggest that the signals bellow $\approx 300 \mathrm{~m} \mathrm{z}^{-1}$ considering $[\mathrm{M}+\mathrm{H}]+/ \mathrm{ESI}+$ are most likely from aglycone parts of secondary metabolites from shikimate/polyketide/mevalonate pathways, while higher $\mathrm{m}$ $\mathrm{Z}^{-1}$ signals are most likely from glycosides (Table 3 ).

\section{Discussion}

Owing to reports regarding the optimal germination rates of "super seeds" at 95\%(de Fátima B Coelho et al., 2011; Li et al., 2020; Su et al., 2017), our findings are thence remarkable for micropropagation purposes; especially when considering that $B$. balansae is a wild variety whose population is decreasing due to the advance of the monoculture of agricultural 
commodities in many regions. Nonetheless, the use of ethanol and sodium hypochlorite as disinfecting agents prior the incubation of the seeds in Murashige-Skoog medium seemingly allowed reliable in vitro germination of $B$. balansae whilst avoiding deleterious microbial contamination (Voll et al., 2010).

Results indicate that both the leaves as well as the roots, regardless of supplementation, did not react to Borntraeger reagent; thereby suggesting low concentrations or absence of anthraquinones and their glycosides (Table 1). This finding is noteworthy since many Bromeliaceae are known to express anthraquinone glycosides (de Oliveira-Júnior et al., 2017). Nonetheless, the oral use of $B$. balansae in Brazilian folk medicine, and the absence of reports regarding purgative effects thereby suggested low concentration of these laxative compounds(da Silva Balin et al., 2018; de Lima et al., 2019; Rocha et al., 2015).

The investigation of flavonoids showcased variable results according to the hydroxylation and saturation of the aglycone, being the detection of flavones positive in the leaves while negative in the roots, regardless of supplementation (Table 1). This result is in consonance to literature, as flavones are reported to be produced in higher yields in the leaves of plants (Amaral et al., 2001).

Regarding the presence of flavonoids, oxalo-boric reaction led to negative results in the leaves and positive results in the roots, regardless of supplementation; while the reaction with concentrated sulfuric acid hinted that all samples showcased flavonoids at least to some degree, what was confirmed in the quantitative analysis (Table 1 and 2). In the same way, the presence of phenols was positive to all samples in all tests (Table 1).

Owing to the fact that flavonoids such as flavones; flavanols and flavanones may be expressed in different tissues and at varied yields (Thomaz et al., 2018b; Zhang et al., 2018), the presence of these polyphenolic compounds at least to some degree in all parts of $B$. balansae is an interesting finding. Nevertheless, the increased expression of flavonoids and phenols in organo-mineral-supplemented plants is remarkable, as it showcases that $B$. balansae increases the production of secondary metabolites when supplemented with macro and micronutrients; what is supported by literature (Yang et al., 2018).

Moreover, the higher yield of total phenols and flavonoids in the roots upon organo-mineral supplementation is also noteworthy; as it showcases that exogenous factor significantly alter the expression of shikimate/polyketide metabolites in different tissues of the plant. Nonetheless, polyphenols are known to play a structural role in plant development, such as the production of lignin for cell wall formation (Liu et al., 2018). In this sense, the increased concentration of these compounds in the roots upon organo-mineral supplementation suggests that the plants assimilated the nutrients from the soil, what may improve their development and survival in the environment.

Concerning the presence of saponins, all samples showcased negative results; while the opposite occurred to coumarins (all samples showcased positive results) (Table 1). The negative results to saponins are in accordance to literature, as other authors describe small yields of saponins in Bromeliaceae(Meza-Espinoza et al., 2017). These compounds are produced by plants mostly as means for animal foraging, though Bromeliaceae are known to express coumarins; which dampen animal interest on feeding on the plant (Iriti et al., 2004; Thomaz et al., 2020). Moreover, many species of this vegetal family also showcase mechanical defenses such as thorns and spines on the edges of their leaves(Romero et al., 2006). Nonetheless, B. balansae are traditionally used as "living fences" in Brazilian livestock farming to prevent animal free roaming.

In the investigation of tannins, the formation of precipitates with gelatin was negative to all samples, while the reaction with copper acetate and with iron chloride led to positive results for the roots regardless of supplementation (Table 1). Moreover, the reaction of the samples with alkaline hydroxides led to positive results in all of them regarding the presence of tannins (Table 1), thereby suggesting at least some amount of this secondary metabolite in the samples. Considering that quantitative analysis showcased a concentration of phenols of about $0.6 \%$ of tannic acid equivalents in all samples (Table 2), 
results therefore suggest a small tannin content; what is in consonance to literature regarding Bromeliaceae phytochemical composition (de Oliveira-Júnior et al., 2017).

The findings of the qualitative phytochemical prospection of alkaloids showcased that all samples are positive to Dragendorff, Bouchardat and Hager reactants, whilst providing negative results to other methods (Table 1). Furthermore, all samples showcased negative results in the investigation of the presence of methylxanthines, regardless of supplementation (Table 1).

Alkaloids are complex compounds whose classification comes from the amino acid from which they originate. In this sense, many tests are used to investigate their presence in samples, being the potassium bismuth iodine (Dragendorff); potassium iodine (Bouchardat) and picric acid (Hager) tests more reactive according to the basicity of the amine moiety in the alkaloid (Petruczynik, 2012; Wang et al., 2019). Therefore, the alkaloids in B. balansae may showcase either secondary amines or short-chained tertiary amines; as increased size might lead to steric hindrance and therefore reduce basicity (Qiu et al., 2014).

Furthermore, considering the wide applicability of alkaloids in medicine, as well as the known antitussive properties of many of these compounds; the presence of alkaloids in all parts of B. balansae may be correlated to the therapeutic indications and use of this plant in folk medicine (Coelho et al., 2010).

Although quantitative analysis showcased higher concentration of phenols and flavonoids in the leaves and roots from organo-mineral-supplemented plants, these spectrophotometric tests promote the overlapped detection of both the glycoside as well as the aglycone of secondary metabolites(Abbattista et al., 2019; Akimoto et al., 2017). Considering that the participation of secondary metabolites in biochemical processes in plants occurs mostly as glycosylated compounds(Jamwal et al., 2018), it can be suggested that the lower relative abundances of the aglycone signals in the supplemented leaves and roots therefore hints that these compounds predominate as glycosides. In this sense, organo-mineral supplementation seemingly enhances the expression of secondary metabolites and also promote their incorporation in other biochemical processes.

Owing to the results from phytochemical prospection, as well as mass spectrometry findings and reports by other authors; it could be suggested that B. balansae express coumarins in their tissues(Stanjek et al., 1999). These compounds are a class of photoreactive compounds which showcase many biological activities, which range from stimulating skin pigmentation to anticancer activity(Thomaz et al., 2020). Although furanocoumarin precursors (i.e., coumarins) were detected in B. balansae by other authors, their role in the biological effects of this plant in folk medicine is still unknown(de Oliveira-Júnior et al., 2017).

Literature describes the expression of phenols in B. balansae tissues(de Lima et al., 2019), what was nonetheless showcased in both the qualitative and quantitative analysis herein conducted. Moreover, CFM-ID and database analysis allowed us to suggest the presence of fragments from phenolic compounds from shikimate (i.e. shikimic acid), as well as shikimic/polyketide pathways (i.e. polyphenols such as flavonoids) in B. balansae mass spectra, thereby contributing to shed light on the secondary metabolite profile of this plant(Akimoto et al., 2017).

Regarding the presence of alkaloids in Bromeliaceae, indolamine derivatives were confirmed in varieties such as $B$. plumieri Mart; what therefore suggests the presence of these compounds in B. balansae (Andrade-Cetto et al., 2013; Bernardello et al., 1991). Moreover, literature describe antitussive activities to tetrahydro- $\beta$-carboline indole derivatives, what matches the therapeutic indications of B. balansae in folk medicine (Zhao et al., 2018). Considering that the qualitative phytopharmacological prospection suggested the presence of alkaloids bearing secondary amine moieties in the samples, it can be strongly suggested the presence of indolamine alkaloids in B. balansae. 


\section{Conclusion}

This work detailed the investigation of the influence of organo-mineral supplementation on the production of secondary metabolites in in vitro-germinated B. balansae. Results showcased that the in vitro germination of B. balansae was successful, with a germination rate of $94.95 \%$, thereby equaling to "super seeds" reported in literature. Moreover, the organomineral supplementation enhances the production of secondary metabolites in both leaves and roots, what therefore leads to higher yield of total phenols and flavonoids. Furthermore, mass spectrometry analysis confirmed the results from phytopharmacological prospection, and allowed the detection of fragments of secondary metabolites from shikimate/polyketide/mevalonate pathways.

\section{Acknowledgments}

Authors thank CAPES-Brazil and FAPEG for the financial support.

\section{References}

Abbattista, R., Losito, I., De Ceglie, C., Basile, G., Calvano, C. D., Palmisano, F., \& Cataldi, T. R. I. (2019). Structural characterization of the ligstroside aglycone isoforms in virgin olive oils by liquid chromatography-high-resolution Fourier-transform mass spectrometry and H/Dexchange. Journal of Mass Spectrometry, 54(10). 10.1002/jms.4438

Akimoto, N., Ara, T., Nakajima, D., Suda, K., Ikeda, C., Takahashi, S., Muneto, R., Yamada, M., Suzuki, H., Shibata, D., \& Sakurai, N. (2017). FlavonoidSearch: A system for comprehensive flavonoid annotation by mass spectrometry. Scientific Reports, 7(1). 10.1038/s41598-017-01390-3

Allen, F., Greiner, R., \& Wishart, D. (2015). Competitive fragmentation modeling of ESI-MS/MS spectra for putative metabolite identification. Metabolomics, 11(1). 10.1007/s11306-014-0676-4

Alves, C. B., Rodrigues, E. S. B., Thomaz, D. V., Filho, A. M. de A., Gil, E. de S., \& Couto, R. O. do. (2020). Correlation of polyphenol content and antioxidant capacity of selected teas and tisanes from Brazilian market. Brazilian Journal of Food Technology, 23. 10.1590/1981-6723.03620

Amaral, D. F., Arruda, M. S. P., Arruda, A. C., Müller, A. H., Pantoja, L. L. J., \& Lima, T. M. D. S. (2001). Flavones from the Leaves of Ficus gomelleira. Journal of the Brazilian Chemical Society, 12(4). 10.1590/S0103-50532001000400016

Andrade-Cetto, A., \& Medina-Hernández, A. E. (2013). Hypoglycemic effect of Bromelia plumieri (E. Morren) L.B. Sm., leaves in STZ-NA-induced diabetic rats. Frontiers in Pharmacology, 4 APR. 10.3389/fphar.2013.00036

Baliza, D. P., Cunha, R. L., Guimarães, R. J., Barbosa, J. P. R. A. D., Ávila, F. W., \& Passos, A. M. A. (2012). Physiological characteristics and development of coffee plants under different shading levels. Revista Brasileirade Ciencias Agrarias, 7(1). 10.5039/agraria.v7i1a1305

Bem Junior, L. Del, Ferrari, J. L., Dario, G., Triboni, Y. de B., \& Raetano, C. G. (2019). Physiological potential and initial development of soybean plants as a function of seed treatment. Pesquisa Agropecuaria Tropical, 49. 10.1590/1983-40632019v4955076

Bernardello, M., Galetto, L., \& Juliani, H. R. (1991). Floral nectar, nectary structure and pollinators in some argentinean Bromeliaceae. Annals of Botany, 67(5). 10.1093/oxfordjournals.aob.a088174

Coelho, R. G., Honda, N. K., Vieira, M. do C., Brum, R. L., Pavan, F. R., Leite, C. Q. F., \& Cardoso, C. A. L. (2010). Chemical composition and antioxidant and antimycobacterial activities of Bromelia balansae (Bromeliaceae). Journal of Medicinal Food, 13(5). 10.1089/jmf.2009.0032

Corrêa, A. C., Carmona, V. B., Simão, J. A., Galvani, F., Marconcini, J. M., \& Mattoso, L. H. C. (2019). Cellulose nanocrystals from fibers of Macauba (Acrocomia Aculeata) and Gravata (Bromelia balansae) from Brazilian Pantanal. Polymers, 11(11). 10.3390/polym11111785

da Silva Balin, P., Zanatta, F. C., Jorge, B. C., Leitão, M., Kassuya, R. M., Cardoso, C. A. L., Kassuya, C. A. L., \& Arena, A. C. (2018). Toxicological evaluation and anti-inflammatory potential of an ethanolic extract from Bromelia balansae (Bromeliaceae) fruit. Journal of Ethnopharmacology, 222. 10.1016/j.jep.2018.04.049

da Silva, M. M. M., da Silva, E. P., da Silva, F. A., Ogando, F. I. B., de Aguiar, C. L., \& Damiani, C. (2017). Physiological development of cagaita (Eugenia dysenterica). Food Chemistry, 217. 10.1016/j.foodchem.2016.08.054

de Fátima B Coelho, M., Vieira, S. N., Chig, L. A., Santos, L. W., \& de F e Albuquerque, M. C. (2011). Overcoming seed dormancy of Bromelia balansae (Bromeliaceae). Horticultura Brasileira, 29(4). 10.1590/S0102-05362011000400005

de Lima, M. C., \& Portari, G. V. (2019). Centesimal composition and antioxidant compounds of two fruits from the Cerrado (Brazilian Savannah). Revista Ceres, 66(1). 10.1590/0034-737X201966010006

de Oliveira-Júnior, R. G., Ferraz, C. A. A., Souza, G. R., Guimarães, A. L., de Oliveira, A. P., de Lima-Saraiva, S. R. G., Rolim, L. A., Rolim-Neto, P. J., \& da Silva Almeida, J. R. G. (2017). Phytochemical analysis and evaluation of antioxidant and photoprotective activities of extracts from flowers of Bromelia laciniosa (Bromeliaceae). Biotechnology and Biotechnological Equipment, 31(3). 10.1080/13102818.2017.1288073 
Delgado, A. M., Issaoui, M., \& Chammem, N. (2019). Analysis of main and healthy Phenolic compounds in foods. Journal of AOAC International, 102(5). 10.5740/jaoacint.19-0128

Hroboňová, K., \& Sádecká, J. (2020). Coumarins content in wine: application of HPLC, fluorescence spectrometry, and chemometric approach. Journal of Food Science and Technology, 57(1). 10.1007/s13197-019-04048-2

Hufsky, F., \& Böcker, S. (2017). Mining molecular structure databases: Identification of small molecules based on fragmentation mass spectrometry data. In Mass Spectrometry Reviews (Vol. 36, Issue 5). 10.1002/mas.21489

Iriti, M., \& Faoro, F. (2004). Plant defense \& human nutrition: Phenylpropanoids on the menu. In Current Topics in Nutraceutical Research (Vol. 2, Issue 1).

Isah, T. (2019). Stress and defense responses in plant secondary metabolites production. In Biological research (Vol. 52, Issue 1). 10.1186/s40659-019-0246-3

Jamwal, K., Bhattacharya, S., \& Puri, S. (2018). Plant growth regulator mediated consequences of secondary metabolites in medicinal plants. In Journal of Applied Research on Medicinal and Aromatic Plants (Vol. 9). 10.1016/j.jarmap.2017.12.003

José, M. T. de A. F., Hyany, A. P. T., Iure, S. de C., Milenna, V. V. de O. A., Nathália, A. C. de S., Tarcísio, C. de L. A., Emanuella, C. V. P., Isabela, A. A., Pedrita, A. S., Pedro, J. R.-N., Larissa, A. R., \& Edigênia, C. da C. A. (2019). Development and validation of an analytical method for quantification of total flavonoids in Alternanthera brasiliana by ultraviolet-visible absorption spectrophotometry. African Journal of Biotechnology, 18(30). 10.5897/ajb2019.16905

Li, H., Cao, S., Luo, X., Chen, L., Jing, D., Tang, L., Zhang, F., Zhao, D., Zhou, T., \& Yuan, X. (2020). A new super soft-seed pomegranate cultivar "Zhongshiliu 5." Journal of Fruit Science, 37(12). 10.13925/j.cnki.gsxb.20200281

Liu, Q., Luo, L., \& Zheng, L. (2018). Lignins: Biosynthesis and biological functions in plants. In International Journal of Molecular Sciences (Vol. 19, Issue 2). $10.3390 / \mathrm{ijms} 19020335$

Majinda, R. R. T. (2012). Extraction and isolation of saponins. Methods in Molecular Biology, 864. 10.1007/978-1-61779-624-1_16

Matias, L. J., Rocha, J., Royo, V. A., Menezes, E., Júnior, A. de M., \& de Oliveira, D. (2019). Phytochemistry in medicinal species of Solanum L. (Solanaceae). Pharmacognosy Research, 11(1). 10.4103/pr.pr_148_18

Meza-Espinoza, L., García-Magaña, M. de L., Vivar-Vera, M. de los ángeles, Sáyago-Ayerdi, S. G., Chacón-López, A., Becerra-Verdín, E. M., Muy-Rangel, M. D., \& Montalvo-González, E. (2017). Ethnobotanical and nutritional aspects, and biological activity of fruit extracts of the genus Bromelia. Revista Fitotecnia Mexicana, 40(4). 10.35196/rfm.2017.4.425-437

Mohana, S., \& Roopa, N. (2012). Study on Extraction of Caffeine from Tea Leaves (Camellia Sinensis). Indian Journal of Forensic Medicine and Toxicology, $6(1)$.

Mole, S., \& Waterman, P. G. (1987). A critical analysis of techniques for measuring tannins in ecological studies - I. Techniques for chemically defining tannins. Oecologia, 72(1). 10.1007/BF00385058

Neto, L. F. de L., Barruffini, A. C. C., Thomaz, D. V., Machado, F. B., \& Macedo, I. Y. L. de. (2019). In silico investigation of possible caffeine interactions with common inflammation-related targets. Journal of Applied Biology and Biotechnology, 7(5). 10.7324/JABB.2019.70505

Oliveira, T. S. de, Thomaz, D. V., Neri, H. F. da S., Cerqueira, L. B., Garcia, L. F., Gil, H. P. V., Pontarolo, R., Campos, F. R., Costa, E. A., Santos, F. C. A. dos, Gil, E. de S., \& Ghedini, P. C. (2018). Neuroprotective effect of caryocar brasiliense camb. leaves is associated with anticholinesterase and antioxidant properties. Oxidative Medicine and Cellular Longevity, 2018. 10.1155/2018/9842908

Petruczynik, A. (2012). Analysis of alkaloids from different chemical groups by different liquid chromatography methods. In Central European Journal of Chemistry (Vol. 10, Issue 3). 10.2478/s11532-012-0037-y

Qiu, S., Sun, H., Zhang, A. H., Xu, H. Y., Yan, G. L., Han, Y., \& Wang, X. J. (2014). Natural alkaloids: Basic aspects, biological roles, and future perspectives. Chinese Journal of Natural Medicines, 12(6). 10.1016/S1875-5364(14)60063-7

Rocha, F. S., Duarte, L. D. S., \& Waechter, J. L. (2015). Positive association between Bromelia balansae (Bromeliaceae) and tree seedlings on rocky outcrops of Atlantic forest. Journal of Tropical Ecology, 31(2). 10.1017/S0266467414000728

Romero, G. Q., Mazzafera, P., Vasconcellos-Neto, J., \& Trivelin, P. C. O. (2006). Bromeliad-living spiders improve host plant nutrition and growth. Ecology, 87(4). 10.1890/0012-9658(2006)87[803:BSIHPN]2.0.CO;2

Rouder, J. N., Engelhardt, C. R., McCabe, S., \& Morey, R. D. (2016). Model comparison in ANOVA. Psychonomic Bulletin and Review, 23(6). 10.3758/s13423-016-1026-5

Sanchez, S., \& Demain, A. L. (2019). Secondary metabolites. In Comprehensive Biotechnology. 10.1016/B978-0-444-64046-8.00012-4

Stanjek, V., Piel, J., \& Boland, W. (1999). Biosynthesis of furanocoumarins: mevalonate-independent prenylation of umbelliferone in Apium graveolens (Apiaceae). Phytochemistry, 50(7), 1141-1146. 10.1016/S0031-9422(98)00650-5

Su, L. qiang, Li, J. guo, Xue, H., \& Wang, X. feng. (2017). Super absorbent polymer seed coatings promote seed germination and seedling growth of Caragana korshinskii in drought. Journal of Zhejiang University: Science B, 18(8). 10.1631/jzus.B1600350

Thomaz, D. V., Peixoto, L. F., de Oliveira, T. S., Fajemiroye, J. O., da Silva Neri, H. F., Xavier, C. H., Costa, E. A., Alcantara dos Santos, F. C., de Souza Gil, E., \& Ghedini, P. C. (2018a). Antioxidant and neuroprotective properties of Eugenia dysenterica leaves. Oxidative Medicine and Cellular Longevity, 2018. $10.1155 / 2018 / 8601028$

Thomaz, D. V., Couto, R. O. do, Roberth, A. de O., Oliveira, L. A. R., Leite, K. C. de S., Bara, M. T. de F., Ghedini, P. C., Bozinis, M. C. V., Lobón, G. S., 
Research, Society and Development, v. 10, n. 11, e411101118052, 2021

(CC BY 4.0) | ISSN 2525-3409 | DOI: http://dx.doi.org/10.33448/rsd-v10i11.18052

Gil, E. de S., \& Machado, F. B. (2018b). Assessment of Noni (Morinda citrifolia L.) product authenticity by solid state voltammetry. International Journal of Electrochemical Science, 13(9). 10.20964/2018.09.390

Thomaz, D. V., Oliveira, M. G. de, Rodrigues, E. S. B., Silva, V. B. da, \& Santos, P. A. dos. (2020). Physicochemical investigation of psoralen binding to double stranded dna through electroanalytical and cheminformatic approaches. Pharmaceuticals, 13(6). 10.3390/ph13060108

Voll, E., Gazziero, D. L. P., \& Adegas, F. S. (2010). Aconitic acid on seeds of weed species from different locations. Planta Daninha, 28(1). 10.1590/s010083582010000100002

Wang, J., Jiang, Y., Wang, B., \& Zhang, N. (2019). A review on analytical methods for natural berberine alkaloids. In Journal of Separation Science (Vol. 42, Issue 9). 10.1002/jssc.201800952

Yang, L., Wen, K. S., Ruan, X., Zhao, Y. X., Wei, F., \& Wang, Q. (2018). Response of plant secondary metabolites to environmental factors. In Molecules (Vol. 23, Issue 4). 10.3390/molecules23040762

Zhang, Z., Liang, Z., Yin, L., Li, Q. X., \& Wu, Z. (2018). Distribution of Four Bioactive Flavonoids in Maize Tissues of Five Varieties and Correlation with Expression of the Biosynthetic Genes. Journal of Agricultural and Food Chemistry, 66(40). 10.1021/acs.jafc.8b03865

Zhao, Y. L., Yang, Z. F., Shang, J. H., Huang, W. Y., Wang, B., Wei, X., Khan, A., Yuan, Z. W., Liu, Y. P., Wang, Y. F., Wang, X. H., \& Luo, X. D. (2018). Effects of indole alkaloids from leaf of Alstonia scholaris on post-infectious cough in mice. Journal of Ethnopharmacology, 218. 10.1016/j.jep.2018.02.040

Zhu, C., Liu, N., Tian, M., Ma, L., Yang, J., Lan, X., Ma, H., Niu, J., \& Yu, J. (2020). Effects of alkaloids on peripheral neuropathic pain: A review. In Chinese Medicine (United Kingdom) (Vol. 15, Issue 1). 10.1186/s13020-020-00387-x 